\title{
Integrated Marketing Communication Model in Shaping Brand Equity and Business Performance in the Creative Industries of Embroidery Sector
}

\author{
Maman Sulaeman ${ }^{1,2}$, Hasan Fahmi Kusnandar ${ }^{3}$ \\ ${ }^{1,3}$ Politeknik Triguna Tasikmalaya, Indonesia \\ ${ }^{2}$ Universitas Perwira Purbalingga, Indonesia \\ mansulaeman1274@gmail.com
}

\begin{abstract}
At this time, competition in the business world is getting tighter, no exception with the embroidery industry. In order to survive in the middle of the competition, they must have the right marketing communication strategy. Marketing communication plays a very important role for marketers. Without communication, consumers and society as a whole will not know the existence of products in the market. This research aims to analyze the integrated marketing communication model in shaping brand equity and business performance in the embroidery industry in Tasikmalaya Regency. The research method used is descriptive causality, by creating a description or description systematically, factually and accurately about the fact or nature of the object and interpreting the relationship between the phenomena investigated. The population of this research is the owner of the embroidery industry in Tasikmalaya of 949 people, sampling in this study is using accidental sampling method obtained 150 people. The results showed that partially and simultaneously direct marketing, personal selling, sales promotion, public relations and advertising on purchasing decisions and impact on business performance. Market attractiveness in addition to influencing purchasing decisions is also very potential to increase market share and growth of a company's business performance.
\end{abstract}

Keywords marketing communications, equity, brands, business

\section{Introduction}

In the midst of competition and various obstacles that must be faced by the embroidery industry in building its marketing communications, they strive to choose the strategy that they consider the most accurate. For example, many embroidery entrepreneurs are willing to spend a large budget with long-duration advertising or by supporting large events. But this is not the case with some embroidery entrepreneurs in kawalu embroidery center tasikmalaya city who prefer direct communication with consumers in their marketing communication strategy. This is done because many types of embroidery are still newly circulated in the market so that a strategy is needed that is relevant to existing conditions, namely with bottom up marketing strategies where marketers sell their products directly to the user. This strategy is chosen because if directly to the retailer then this product will be rejected because consumers do not know it. Furthermore, after the comments know about this product and its quality, marketers will start introducing their products to sellers or shops. In addition, there are still many companies that rely on one or two communication tools. Even this practice has been maintained even though the mass market has been fragmented into many small markets, each of which requires its own 
approach. Marketing managers still think that the most effective promotional activity is advertising through the mass media. This assumption causes the promotional function of a company is generally dominated by mass media advertising. The Company relies on advertising agencies to provide guidance and advice to management on almost everything related to marketing communications. The phenomenon that occurred in the center of embroidery Tasikmalaya city are:

1. Entrepreneurs in embroidery centers many prefer direct communication with consumers in their marketing communication strategy that is by looking for their own orders, and marketing themselves.

2. Many entrepreneurs rely on one or two communication tools such as using only direct sales and advertising.

3. Marketing managers until now still exist who think that the most effective promotional activities are advertising through the mass media. This assumption causes the promotional function of a company is generally dominated by mass media advertising.

4. Public Relations has not been seen as an integral participant in the company's promotional activities

5. Visitors who come a lot who just look around the type of embroidery and do not so buy

6. Most embroidery entrepreneurs do not have regular customers

Other forms of marketing communication, in addition to advertising in mass media, such as sales promotion or direct marketing are still considered additional work and are more commonly used in certain cases only. Public relations consultants are only used to manage publicity activities, manage imagery and handle affairs with the public. Public Relations has not been seen as an integral participant in the company's promotional activities. Marketing managers in the past have made a clear boundary between marketing and promotional functions. They plan and manage marketing and promotional activities on a separate budget. They have different views on the market as well as different destinations. The Company fails to understand that various marketing and promotional efforts must be coordinated in order to carry out its communication functions effectively and to provide a consistent image to the market

\section{Review of Literatures}

\subsection{Integrated Marketing Communication}

According to the American Association of Advertising Agencies (the"4As") it is stated in a book written by Belch (2013:11) that: Integrated marketing communication is the concept of marketing communication planning that recognizes the added value of a comprehensive plan that evaluates the strategic role of various communication disciplines e.g., general communication, direct response, sales promotion and public relations and combines these disciplines to provide maximum clarity, consistency, and communication influence through the complete integration of different messages. According to Kholil et al (2019) Communication planning is one thing that is very urgent to do in urban development activities. This is important, because communication planning aims to help achieve programs effectively and efficiently. Wirawan in Arif et al (2019) argues that performance is the output produced by the functions or indicators of a job or a profession within a certain time.

With increasing emphasis on customer and stakeholder relationships, both academics and professionals have sought to provide a variety of names for processes designed to help organizations be more customer-centered. In addition to integrated marketing communication (IMC), there is customer relationship management (CRM), one-to-one marketing, integrated 
marketing (intregrated marketing). While each has its point of difference, all are designed to do one thing-fundamentally increase the value of a company or brand by allowing organizations to acquire, maintain, and develop relationships with customers cost-effectively. "Developing" customers means motivating them to give a greater share of their spending to buy a particular brand.

IMC was one of the first processes established to manage customer relationships. It is also the most widely used. The thing that sets IMC apart from other customer-based business creation processes is that IMC's foundation is communication, which is at the heart of all relationships, and it's a rotating process, not a linear process. There is no beginning and end with regard to the business of acquiring, retaining, and developing customers (Duncan, 2012: 8). According to Morissan (2010:7), marketing communication activities include: 1) advertising (advertising) 2) direct marketing 3) sales promotion 4) personal selling 5) interactive marketing; and 6) public relations. Of these six things that marketing communication can take place by combining these things so that marketing communication can run up and effectively.

\subsection{Brand Equity}

Some experts provide a multifaceted brand equity define. According to Aaker (1991), brand equity is a set of brand assets and liabilities related to a brand, its name and symbol, which adds to or decreases the value provided by a product or service to a company or its customers. Kotler and Keller (2013: 263), brand equity is a plus given to products and services. Brand equity can be reflected in the way consumers think, feel and act in relation to the brand as well as the price, market share and profitability that the brand provides to the company. Of these two definitions brand equity is influenced by the value of a product and service. This value reflects in the form of the way a consumer thinks, feels, and acts on the brand, price, market share, and profitability that the company has. The Brand Equity model is a model developed by David A. Aaker which is an extension of the brand equity concept. In this model, measurements are grouped into five categories. The first five categories represent consumer perception of a brand through 5 dimensions of brand equity, namely brand awareness, quality perception, brand association, brand loyalty and other assets.

\subsection{Business Performance}

Performance measurement relies heavily on the performance indicators used. Performance indicators according to Donald and Lawton in Jeremiah (2016) are presented as follows: "that performance can be measured from measure throughput orientation output (result-oriented non-process-oriented measures), efeciency (efficiency), effektiveness (effectiveness)". Meanwhile, according to Salim and Woodward (2016), performance can be measured from several indicators, including: "work load or demand, economy efficiency, effectiveness, and equity. Performance indicators must be something that will be calculated and measured and used as the basis for assessing or looking at the level of performance, both in the planning stage, the implementation stage and the stage after the activity is completed.

Consumers can learn about who makes the product and what the company and brand's goals are. Marketing communications allow companies to connect their brands with people, venues, events, brands, experiences, feelings and more. They can contribute to brand equity by instilling brands in memory and creating brand image as well as driving sales and even influencing shareholder value. (Kotler \& Keller, 2012:172-173). The implementation of integrated marketing communication aims to build a company brand in the minds of consumers or customers. Brands are becoming more considered by companies today, especially in increasingly sharp brand competition conditions. The brand must have more 
quality so that a brand can be known and have its own uniqueness. The Brand shall contain assets and liabilities that add to or decrease the value that a goods or service provides to the company or customer of that company (brand equity).

Marketing performance is an important element of a company's performance in general because the performance of a company can be seen from its marketing performance so far. Marketing performance is a concept to measure a company's marketing achievements. Every company has an interest to know its achievements as a mirror of the success of its business in market competition.

\section{Research Methods}

In this study, researchers took the method of research descriptive causality because it is done by making a description or description systematically, factually and accurately about the fact or nature of the object and interpreting the relationship between the phenomena investigated. This research was conducted in the embroidery industry Tasikmalaya Regency. The object in this study was the owner of embroidery industry as many as 949 people with a sample of 150 people, with the scope of this research, limited to the application of integrated marketing communication, brand equity and business performance. The variables used in the research are integrated awareness communication as a free variable, brand equity and business performance as bound variables. In this study using primary type data with interview method, namely data sourced from the results of answers to questionnaires or interviews conducted with materials related to this research. The data sources were obtained from the Tasikmalaya MSME Office, Journals and Previous Research, and literature related to this research.

The Inferential Statitic Method used in the analysis of this research data is the path of analysis. The reason for using the path of analysis, the consideration that the caesal relationship formulated in this study uses a not simple model that plays a double role as. This form of causal relationship requires analysis that is able to explain simultaneously about the relationship so that the method used in this study uses the path of analysis.

\section{Results and Discussion}

The results of data processing can be known partial influence of direct marketing, personal selling, sales promotion, public relations and advertising on purchasing decisions can be seen in Table 1 below:

Table 1. Partial Influence of Direct marketing, Personal selling, Sales Promotion, Public relations and Advertising on Purchasing Decisions

\begin{tabular}{|c|c|c|c|c|c|c|}
\hline \multirow{2}{*}{\multicolumn{2}{|c|}{ Model }} & \multicolumn{2}{|c|}{$\begin{array}{l}\text { Unstandardized } \\
\text { Coefficients }\end{array}$} & \multirow{2}{*}{\begin{tabular}{|l}
$\begin{array}{c}\text { Standardized } \\
\text { Coefficients }\end{array}$ \\
Beta \\
\end{tabular}} & \multirow[b]{2}{*}{$\mathrm{t}$} & \multirow[b]{2}{*}{ Sig. } \\
\hline & & B & Std. Error & & & \\
\hline \multirow[t]{6}{*}{1} & (Constant) & .312 & 1.197 & & .260 & .795 \\
\hline & Direct marketing & .370 & .127 & .166 & 2.902 & .004 \\
\hline & Sales Promotion & .594 & .146 & .282 & 4.065 & .000 \\
\hline & Public relations & .299 & .078 & .107 & 3.838 & .000 \\
\hline & Personal selling & .297 & .159 & .143 & 1.869 & .044 \\
\hline & Advertising & .443 & .104 & .352 & 4.243 & .000 \\
\hline
\end{tabular}




\begin{tabular}{|c|c|c|c|c|c|c|}
\hline \multirow{2}{*}{\multicolumn{2}{|c|}{ Model }} & \multicolumn{2}{|c|}{$\begin{array}{c}\text { Unstandardized } \\
\text { Coefficients }\end{array}$} & \multirow{2}{*}{\begin{tabular}{|c|}
$\begin{array}{c}\text { Standardized } \\
\text { Coefficients }\end{array}$ \\
Beta \\
\end{tabular}} & \multirow[b]{2}{*}{$\mathrm{t}$} & \multirow[b]{2}{*}{ Sig. } \\
\hline & & B & Std. Error & & & \\
\hline \multirow[t]{6}{*}{1} & (Constant) & .312 & 1.197 & & .260 & .795 \\
\hline & Direct marketing & .370 & .127 & .166 & 2.902 & .004 \\
\hline & Sales Promotion & .594 & .146 & .282 & 4.065 & .000 \\
\hline & Public relations & .299 & .078 & .107 & 3.838 & .000 \\
\hline & Personal selling & .297 & .159 & .143 & 1.869 & .044 \\
\hline & Advertising & .443 & .104 & .352 & 4.243 & .000 \\
\hline
\end{tabular}

a. Dependent Variabel: Purchasing Decisions

\subsection{Partial Influence of Direct Marketing on Purchasing Decisions}

The partial effect of direct marketing on its purchase decisions or $\rho Y X 1$ was 0.166 . For partial hypothesis testing the influence of direct marketing (X1) on purchasing decisions (Y) with Ho rejection criteria if $\mathrm{t}$ calculate $>\mathrm{t}$ table . Spss calculation results obtained $\mathrm{t}$ count $=$ 2,902 while $t$ table of 1,703 thus $t$ calculate $>t$ table so that it can be said that there is a positive influence of direct marketing on purchasing decisions.

Face-to-face selling has the advantage that salespeople can convey information about the characteristics of products sold more complexly compared to other advertising media such as electronic media or print media, in addition salespeople can also demonstrate products sold directly to potential consumers to gain the attention and feedback of consumers themselves. This is in accordance with the face to face selling sales carried out, where salespeople explain directly to consumers about the characteristics of the products sold and demonstrate coffee making to potential consumers so as to cause consumer interest to buy the products offered.

This is in accordance with the advertising model Model Lavidge Gary Steiner (Kasali, 2007) that is, communication that begins with the awareness of introducing products through simple messages continuously by repeating the product name will encourage the target market (consumers) have more knowledge about the products sold by conveying information about the product so that consumers will be interested in buying but vice versa if communication is rarely done consumers will turn to other products that more often offer their products continuously (Kasali , 2007).

\subsection{Partial Influence of Sales Promotion on Purchasing Decisions}

Partial effect of sales promotion on purchasing decisions or $\rho Y X 2$ of 0.282 . For partial hypothesis testing the effect of sales promotion (X2) on purchasing decisions(Y) with Ho rejection criteria if $\mathrm{t}$ calculate $>\mathrm{t}$ table . Spss calculation results obtained $\mathrm{t}$ count $=4,065$ while $t$ table of 1,703 thus $t$ calculate $>t$ table so that it can be said that there is a positive influence of sales promotion on purchasing decisions. Sales promotions are intended to communicate with consumers at the place of sale so that consumers are increasingly interested in buying the product. Sales promotion in general can be distinguished into two parts, namely customer oriented sales promotion and trade-oriented sales promotion. Customer oriented sales promotion is aimed at product buyers, among others, such as providing coupons, providing product samples, discounts, valuable sweepstakes, contests and so on. This kind of promotional instrument can attract consumers to buy so as to increase the sales value of the company in the short term. With sales promotions, the process of forming the final decision of consumers will be measured. The influence or stimuli given to 
consumers can be directly seen the results, consumers are interested or not with the sales promotion program carried out.

Buchari Alma (2016:210) says in his theory that between promotion and product can not be separated, these two lovebirds are each other to lead to successful marketing. Here there must be a balance of good products in accordance with consumer tastes, coupled with the right promotional techniques will be very helpful suksenya marketing efforts. It appears that the theory states that the right promotional techniques help the success of marketing efforts

\subsection{Partial Influence of Public Relations on Purchasing Decisions}

The partial effect of public relations on its purchasing decision or $\rho Y X 3$ was 0.107 . For partial hypothesis testing the influence of public relations (X3) on purchasing decisions(Y) with Ho rejection criteria if $\mathrm{t}$ calculate $>\mathrm{t}$ table . The calculation result is obtained $\mathrm{t}$ count $=$ 3,838 while the table $t$ is 1,703 thus $t$ calculate $>t$ table so that it can be said that there is a positive influence of public relations on purchasing decisions. In public relations there is an effort to realize a harmonious relationship between an agency and its public, by giving or instilling a pleasant impression; so that public opinion will arise favorable for the survival of the company. Public relations is a management function that conducts communication to generate understanding and acceptance. Public relations has a strategic objective, namely to read the obstacles that arise from the outside and try to overcome them so that the company's goals can be achieved. Public relations contributes greatly to the company by developing harmonious relationships with its public goals. Pleasant harmonious relationships and a sense of trust formed by public relations companies also form a purchasing decision. Through publication activities against the company can affect the image of the company and especially on the products marketed. Therefore, in the formation of purchasing decisions, the role of Public relations becomes very important. This role is also related to the use of mass media as a means of disseminating information activities carried out by the company in shaping consumer opinions on products as well as to the companies that overshadow these products.

Cutlip, et al (2006:6) argues that public relations as a management function that builds and maintains a good and beneficial relationship between the organization and the public that affects the success or failure of the organization. According to Sangadji and Sopiah (2013:225) Advertising aims to increase the reaction of prospective buyers or potential buyers to the company and the company's product offerings. Ads are designed to increase product sales and company profits. Today's challenging media environment, good advertising will produce satisfactory results (Kotler and Keller, 2009:202). The essence of advertising is to influence the minds of consumers and encourage consumers to act on buying.

\subsection{Partial Influence of Personal Selling on Purchasing Decisions}

The partial influence of personal selling on purchasing decisions or $\rho \mathrm{YX} 4$ amounted to 0.143. For partial hypothesis testing the influence of personal selling (X4) on purchasing decisions(Y) with Ho rejection criteria if $t$ calculate $>t$ table. Spss calculation results obtained $t$ count $=1,869$ while $t$ table of 1,703 thus $t$ calculate $>t$ table so that it can be said that there is a positive influence of personal selling on purchasing decisions.

Personal selling is an interactive system and free dialogue that uses one or more forms of media communication to produce a measurable behavioral response effect in each location. By direct communication, it can produce and build a direct relationship between companies that market products with consumers individually. For that Personal selling is one form of effective sales. This is also related to the fulfillment of direct information obtained by consumers. Communication that is individual and personal in personal selling allows the 
seller to customize the message based on special needs or special situations of prospective buyers. Personal selling allows direct and more appropriate feedback because the impact of sales presentations can be assessed from the reaction of prospective buyers.

Sales is one of the most important goals for a company. Whether or not a company succeeds depends on the sale of the company. An effective and efficient form of marketing activity is promotion. According to Kotler and Armstrong (2012:76), "Promotion means activities that communicate the merits of the product and persuade target customers to buy it", meaning that promotion is an activity of communicating the benefits of a product and persuading target consumers to buy the product

\subsection{Partial Influence of Advertising on Purchasing Decisions}

The partial effect of advertising on its purchase decision or $\rho Y X 5$ was 0.352 . For partial hypothesis testing the influence of advertising (X5) on purchasing decisions(Y) with Ho rejection criteria if $t$ calculate $>t$ table . The calculation result is obtained $t$ count $=4,243$ while the table $\mathrm{t}$ is 1,703 thus $\mathrm{t}$ calculate the $>\mathrm{t}$ table so that it can be said that there is a positive influence of advertising on purchasing decisions.

This means that increasingly interesting and frequently served ads can increase purchase decisions. Advertising in mass media, information from colleagues, and advertising done by marketers will be able to encourage the creation of consumer decisions for the purchase of products. Advertising is a stage to build consumer awareness of marketed products. Therefore, ads tend to be impulsive. At the time of advertising done by marketers after going through the evaluation of alternative purchases and getting the choice is in accordance with what is felt by consumers and in accordance with what is expressed in advertising, then positive behavior for purchases will be able to occur, and vice versa if after the evaluation the consumer does not feel conformity with the content of the advertising carried out then the behavior is not good for the purchase will be given by the consumer.

\subsection{Effect of Purchasing Decisions on Business Performance}

The effect of purchasing decisions on business performance

Table 2. Effect of purchasing decisions on business performance Model Summary

\begin{tabular}{|l|l|l|l|l|}
\hline Model & R & R Square & Adjusted R Square & Std. Error of the Estimate \\
\hline 1 & $.956^{\mathrm{a}}$ & .913 & .910 & 2.14093 \\
\hline
\end{tabular}

a. Predictors: (Constant), business performance

Market attractiveness in addition to influencing purchasing decisions is also very potential to increase market share and growth of a company's business performance. because it involves market size, growth rate and assessment of demographics, sociocultural, economic, political and legal, technology and nature that can affect market demand. Resources are also productive assets owned by the company, moreover the company also has the ability to run a company that is a valuable asset. The resources themselves will have no value, resources must be developed based on the ability of the company to improve the business performance of a company. Consumer purchasing decisions are crucial to the sustainability of a company, so every effort will be made to get purchasing decisions from consumers, but this is not easy to do given the competition that will be faced by each company. Then each company will try to maximize the possible to get purchases from consumers who are very influential on the performance of a company. 


\section{Conclusion}

Based on the results of the research, it can be concluded that partially and simultaneously direct marketing, personal selling, sales promotion, public relations and advertising on purchasing decisions and impact on business performance. Market attractiveness in addition to influencing purchasing decisions is also very potential to increase market share and growth of a company's business performance.

\section{Acknowledgements}

This research was supported by the Ministry of Research, Technology and Higher Education through the Directorate of Research and Community Services (DRPM), Penelitian Dosen Pemula Scheme 2020. Therefore, we would like to express our sincere gratitude. Any opinions, findings, and conclusions or recommendations expressed in this article are those of the authors and do not necessarily reflect the views of the respected ministry.

\section{References}

Arif, S., et al. (2019). Influence of Leadership, Organizational Culture, Work Motivation, and Job Satisfaction of Performance Principles of Senior High School in Medan City. Budapest International Research and Critics Institute-Journal (BIRCI-Journal). P. 239254.

Chan Syafruddin. 2013. Relationship Marketing: Inovasi Pemasaran yang Membuat Pelanggan Bertekuk Lutut. Jakarta:PT. Gramedia Pustaka Utama.

Duncan, 2015. Principles of Advertising and Komunikasi Pemasaran Terpadu, 2nd edition New York: McGraw-Hill

Estaswara, 2012, Think IMC: Efektifitas Komunikasi Untuk Meningkatkan Loyalitas Merek dan Laba Perusahaan.Jakarta: Gramedia Pustaka Utama

Goni Roy 2017. Jurnal Ekonomi dan Bisnis, Fakultas Ekonomi Universitas Gajah Mada Yogyakarta.

Hasan, Ali. 2018 Marketing dari Mulut ke Mulut, Jakarta: Medpress

Kholil, S., et al. (2019). Communication Planning of Langsa City Government in Building an Islamic and Environmentally Friendly City. Budapest International Research and Critics Institute-Journal (BIRCI-Journal). P. 638-644.

Kottler, Philip. 2016. Marketing Management. Edisi 8. Prentice Hall International

Mowen, J. C., Minor, M. 2012. Costomer Behavior, 5th Edition, dalam Sumarwan,

Mulyana, Dedi, 2014. Pengantar Ilmu Komunikasi. Bandung: Rosdakarya.

Prisgunanto, Ilham. 2016. Komunikasi Pemasaran: Strategi dan Taktik. Bogor: Ghalia Indonesia

Purba, Amir, dkk. 2016. Pengantar Ilmu Komunikasi. Medan: Pustaka Bangsa Press.

Setiadi, Nugroho. 2015. Perilaku Konsumen Konsep dan Implikasi untuk Strategi dan Penelitian Pemasaran. Prenada Media, Jakarta

Shimp, 2013, Periklanan Dan Promosi Penjualan, Aspek Tambahan Komunikasi Pemasaran Terpadu, Jilid II Edisi Ke 5, Oleh Dr.Dwi Kartini Yahya,S.E.M.M. Jakarta, Erlangga

Sugiono, 2013, " Metode Penelitian Bisnis ", CV. Edisi Pertama, Alfa Beta, Bandung

Sulaksana Uyung. 2013, Komunikasi Pemasaran Terpadus. Pustaka Pelajar.

Sustina, 2013, Perilaku Konsumen \& Komunikasi Pemasaran, Pengantar Prof. Dr. Teddy Pawitra, cetakan pertama, Bandung Penerbit PT. Remaja Rosdakarya.

Tjiptono. Fandy, 2013 Strategi Pemasaran. Yogyakarta: Andi 